\title{
The reintroduction of the swift fox Vulpes velox to South Central Saskatchewan, Canada
}

\author{
Clio Smeeton and Ken Weagle
}

\begin{abstract}
The Canadian Swift Fox Reintroduction Programme lasted from 1972 to 1997 . From 1983 to 1997, a total of 841 captive-raised swift foxes and 91 translocated swift foxes were released in the Canadian Prairies. In South Central Saskatchewan, 406 captiveraised animals and 14 translocated animals were released from 1990 to 1997. This area was used to develop new release methods (in particular, portable protective shelters (PPS)) and saw the co-operation of a nongovernmental organization (NGO) (Cochrane Ecological
\end{abstract}

Institute (CEI)) with two levels of government (Heritage Canada (Grasslands National Park) and the Government of Saskatchewan). A 1996-97 survey of swift foxes in South Central Saskatchewan estimated the population to be 87 animals. No attempt has been made to establish if this population level is sustainable.

Keywords Canada, Saskatchewan, swift fox, Vulpes velox, reintroduction.

\section{Introduction}

Two species of fox, the kit fox Vulpes macrotis and the swift fox Vulpes velox, are native to the Great Plains of North America. Historically, the swift fox range coincided with that of the North American bison Bison bison. The range extended from the Texas panhandle and New Mexico, USA, in the south, to the Aspen parkland of Saskatchewan and Alberta, Canada, in the north, and eastward from the foothills of the Rocky Mountain chain to Manitoba, Canada and to the Mississippi River in the USA.

Swift foxes are North America's smallest canid, weighing between 2.3 and $3.2 \mathrm{~kg}$. They are opportunistic feeders, eating seeds, berries, grass, insects, amphibians, reptiles, and small animals and birds (Uresk \& Sharps, 1986; Bremner, 1997). If water is available, they require $210 \mathrm{~g}$ of food per day; in the absence of water, the foxes absorb their necessary liquid from their food and require $330 \mathrm{~g}$ of food per day (Flaherty \& Plaake, 1986). Swift foxes are preyed upon by both terrestrial and avian predators and are extremely den-dependent. Swift foxes are sedentary, social and largely monogamous. They rely on the burrows of other species for survival, using them as escape terrain and den sites. Swift foxes are, in general, more active at night than

\footnotetext{
Clio Smeeton (corresponding author) Cochrane Ecological Institute, PO Box 484, Cochrane, AB, Canada TOL OWO. Tel.: +1403932 5632; fax + 1403932 6303; e-mail: cei@cadvision.com
}

Ken Weagle Mackenzie Valley Land and Water Board, PO Box 2130, Yellowknife, NT, Canada X1A 2P6

Revised manuscript accepted for publication 3 March 2000 during the day, but this activity pattern varies with the season (Pruss, 1994; Teeling, 1996).

A subspecies of the swift fox, the northern swift fox Vulpes velox hebes, described by Merriam (1902), was briefly listed by the US Department of the Interior in 1974 as endangered in the USA. The species was delisted on the basis that a valid subspecific variation did not exist, supported by Hall's statement that Vulpes velox was conspecific with Vulpes macrotis (Hall, 1981). By 1980, the northern swift fox had vanished throughout its Canadian range and from much of its northern range in the USA, reducing the possibility of subspecies verification. Definitive research, combining morphological and molecular systematic data (Stromberg \& Boyce, 1986; Wayne, 1998), has resulted in the acceptance of distinct taxonomic descriptions for the kit fox Vulpes macrotis and the swift fox Vulpes velox.

The swift fox was classified as extirpated in Canada in 1978 by the Committee on the Status of Endangered Wildlife in Canada (COSEWIC, 1978) and, in 1995, was described as extirpated over 90 percent of its historic range in the USA (United States Federal Register 60(116), 1995). The causes of the extirpation of this species were attributed to the rapid and radical change of the Great Plains ecosystem from native grasslands to cultivated farmland, and the inevitable hunting, trapping and poisoning programmes which accompany such habitat transformation (Carlington, 1980; Weagle \& Smeeton, 1995).

\section{History of the swift fox captive-breeding programme in Canada}

Captive-breeding of the swift fox for reintroduction into its original Canadian range was initiated in 1972, at 
the Wildlife Reserve of Western Canada (now the Cochrane Ecological Institute (CEI)), using four founder foxes from the USA. The captive-breeding programme was initiated solely to provide swift foxes for reintroduction and not for exhibition purposes. Over the period of the programme, the CEI has continued to acquire swift foxes to add to the captive colony from the USA. No Canadian animals were available for addition to the swift fox captive-breeding programme as the species had been extirpated from that country.

By 1997, the CEI held 25 pairs of swift foxes and the captive-breeding programme had provided 841 swift foxes for the Canadian reintroduction programme. These were the progeny of 187 animals, of which 34 (17 males, 17 females) came directly from wild stock from Colorado, Wyoming and South Dakota. A swift fox studbook was started by M. R. Smeeton in 1972 and was transferred to International Species Information System (ISIS) software in 1986. This software is used to ensure maximum genetic heterozygosity in new breeding pairs (inbreeding coefficient $<0.05$ ) and that animals of the same blood lines are not repeatedly reintroduced into the same geographic area (ISIS, 1989).

\section{The Canadian Swift Fox Reintroduction Programme}

After founding the CEI's captive-breeding colony in 1972, Miles and Beryl Smeeton signed a co-operative agreement with Dr Steven Herrero, Dean of the Faculty of Environmental Design, University of Calgary in 1977. This agreement outlined a series of research projects to be conducted as MSc theses (Carlington, 1980; Reynolds, 1983; Schroeder, 1987) on potential release sites and methodology. The Smeetons agreed to provide swift foxes for reintroduction and opened their facility to University of Calgary researchers. In mid1980, on the advice of the newly formed Swift Fox Propagation Committee, swift foxes from the CEI captive-breeding colony were sent to three zoos (Calgary, Edmonton, and Moose Jaw) as breeding and educational exhibit animals. By 1997, none of the zoos participating in the breeding programme had swift foxes, having either returned their swift fox stock to the CEI, or released or euthanized the animals.

The Canadian Wildlife Service (CWS), a branch of the Federal Government of Canada, became involved for the first time in the programme in 1978, when the COSEWIC designated the swift fox as 'extirpated' in Canada. The federal government's jurisdictional involvement in the swift fox reintroduction programme was joined by provincial government involvement when the provinces of Alberta (1983) and Saskatchewan (1985) permitted swift fox releases within their jurisdic- tion. In 1986, the ownership of the captive-breeding colony was transferred to the CWS, although the colony was still housed at CEI and maintained by CEI staff. From 1986 to 1997, the colony was managed under a research permit (0336GP) issued by the Alberta Government to the CWS. In 1997, the province of Alberta issued a Zoo Permit to the CEI, which resulted in ownership of the captive colony reverting to the CEI from the federal government (CWS). The CEI currently holds 16 pairs of swift foxes within single-pair enclosures and five individuals within a 9-ha enclosure.

In addition to the 841 captive-bred swift foxes released in Canada (1983-97), the Canadian Government authorities also undertook a trapping and translocation programme, taking wild swift foxes from the USA for release at Canadian sites. Supplementing the captivebred releases, a total of 91 wild swift foxes were taken from Colorado and Wyoming. In an attempt to determine the most suitable time in the year for the release of swift foxes in the wild, the Swift Fox Recovery Team undertook a multi-year feasibility study. Of the 91 wild swift foxes imported from the USA, 33 were used in a spring release experiment.

The spring release experiment (1989-91) required that wild adult swift foxes were trapped in January in the USA and taken to Canada, where they were quarantined over the breeding season until April. They were then released with a comparable number of captive-bred juveniles born the previous year and retained for this purpose. The experiment involved the tracking of 122 captive-bred and 33 wild translocated animals over this period.

The results showed that the survival of the 41 captive-raised juveniles used in the spring release experiment ( 7.4 per cent) was significantly lower than that of the 33 adult, wild, translocated swift foxes from the USA (58.9 per cent) (Brechtel et al., 1993). The survival of 81 radio-collared captive-raised juvenile animals released in the autumn was significantly higher at 39.7 per cent. Unfortunately, no data were provided for the survival of adult, wild, translocated animals from the USA that were released in the autumn, because none of them were radio-collared (Brechtel et al., 1993). Hjertaas (1994) also analysed the data for the Wood Mountain area of Saskatchewan. His estimates of 12month survival based on daily mortality rates were as follows: spring released, captive-raised swift fox (3.5 per pent); autumn released, captive-raised juvenile swift fox ( 37 per cent); and adult, wild, translocated swift fox from the USA ( 31 per cent). The reasons for these differences in 12-month survival rates calculated from the same data were not investigated.

Two conclusions were drawn from this spring versus autumn/captive-bred versus wild experiment. (1) The 
government authorities concluded that captive-bred animals were less suitable for reintroduction than adult, wild, translocated swift foxes (Brechtel et al., 1993). (2) The CEI concluded that captive-bred animals were effective in conservation terms, provided releases were conducted in the autumn. Of the two options, translocation and captive-bred reintroduction, the latter is generally accepted to be more effective provided there is a viable breeding population of captive animals. Captive-breeding supplements the remaining wild population, if such a population exists, whereas translocation only serves to move it around, often resulting in greater fragmentation of an already threatened species (Tudge, 1991).

Following this experiment, the reintroduction of captive-bred swift foxes continued at various release sites. From 1981 to 1984, the University of Calgary and the CWS were responsible for swift fox release site selection (Carlington, 1980; Reynolds, 1983). On the other hand, government agencies were only responsible for releasing swift foxes onto the Canadian Prairies from 1985 to 1992 . Their scatter-shot methods of site selection resulted in the distribution of small numbers of animals over large areas (Fig. 1). The aim of the National Recovery Plan for the Swift Fox in Canada was to establish a viable self-sustaining population, well distributed across suitable habitats on the Canadian Prairies which would result in the removal of the species from the endangered category by the year 2000' (Brechtel et al., 1994; authors' italics). The hope was that a wide distribution of foxes would populate a larger area more quickly in compliance with the goals of the National Recovery Plan.

The release site selection was intended to result in swift fox occupancy of two large areas, one on the Alberta-Saskatchewan-Montana border and the other

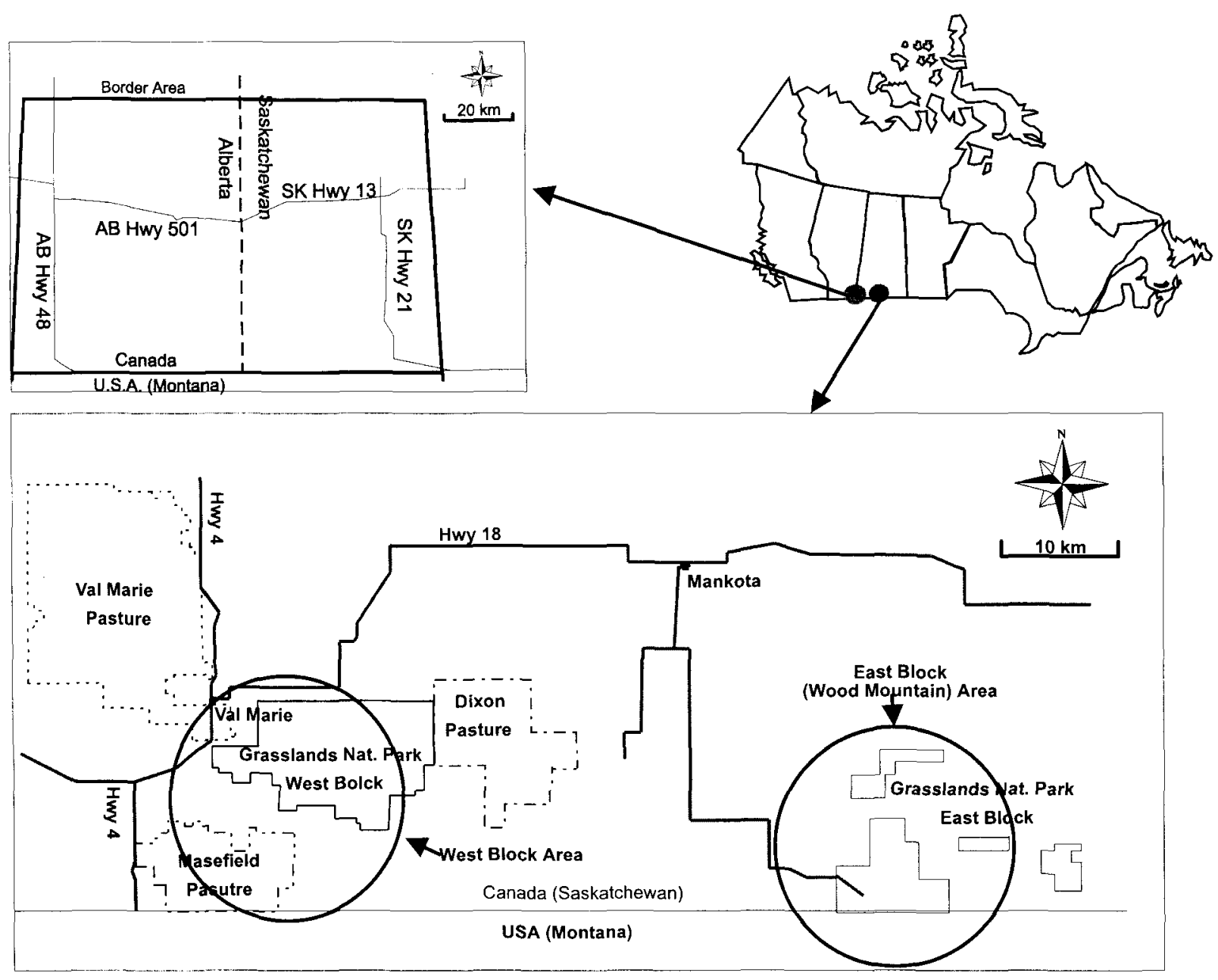

Fig. 1 The location of the primary release sites for the Canadian Swift Fox Reintroduction Programme. 
in South Central Saskatchewan (Fig. 1). Prior study of both these populations was limited and of mixed success. From 1989 to 1991, the governments of Canada, Alberta and Saskatchewan released a total of 520 swift foxes in Canada. Of these, 122 captive-bred and 33 wild, translocated animals (29.8 per cent) were radiocollared and tracked for up to 2 years (Brechtel et al., 1993). In addition, some winter scat and scent post surveys and spring (breeding season) trapping of swift foxes in the reintroduction sites were conducted (Carbyn, 1995). The western population established itself and appeared to increase slightly, but the eastern population did not appear to establish itself but shrunk from its original area. Speculation regarding the reasons for the lack of success in the eastern population varied from poor habitat to the lower survival rates of captive-bred animals (Hjertaas, 1994).

\section{Release methods}

Three specific release methods were used in the reintroduction programme:

1. University of Calgary-At the start of the programme (1983-85), swift foxes were released using the 'soft release' method. This consisted of constructing $3.7 \times 7.3 \mathrm{~m}$ enclosures in the release site where pairs of swift foxes were over-wintered and kept until the following summer when the captive animals and their young, if any, were released. The animals in the enclosures had to be fed and watered. To reduce the travel time of the keeper, large amounts of meat were deposited in the enclosures. This method worked well for the swift fox because known recruitment outweighed known loss, but it was expensive in terms of equipment and staff time. Moreover, the feed provided to the swift foxes was considered to attract predators (Reynolds, 1983; Brechtel et al., 1993).

2. Federal and Provincial Government-In 1985, the soft release method was changed to the 'hard release' method. Hard release consisted of transporting swift foxes, contained in small plastic kennels, to designated release sites and releasing them from the kennel onto the prairie. All sites were within $0.5 \mathrm{~km}$ of a road. No post-release monitoring was undertaken. The hard release method was cheap in terms of equipment and staff time; its rapidity meant that more animals could be released in a shorter period. The hard release method became the method of choice of the Swift Fox Recovery Team.

Using the hard release method, swift foxes were taken up at the breeding colony and placed in plastic transport kennels at least 2 days prior to release. One day was spent trapping and kennelling captive-bred swift foxes intended for release. Swift foxes were captured either by a round-up method using many volunteers or were live-trapped. Once in their kennels, swift foxes were stacked in a holding area overnight. The following day, after receiving prophylactic inoculations and health checks by a veterinarian, they were transported to the release sites (a journey of between 8 and $10 \mathrm{~h}$ ). On arrival at the release area, the kennelled animals remained stacked in the truck as it drove from site to site. This procedure could add a further $10 \mathrm{~h}$ to the time the animals spent in their kennels (up to $58 \mathrm{~h}$ in total) (Brechtel et al., 1993).

3. CEI-In 1992, the CEI became involved with the field releases for the first time. The CEI considered that there were many questions of animal welfare associated with the hard release method, and that it was of vital importance that reintroduced swift foxes be encouraged to stay in the release sites during their initial period of acclimatization to the area. CEI involvement resulted in the development of the third release method using portable protective shelters (PPS). The CEI method had four components and was shown to reduce the stress on the transported swift foxes and to increase their initial survival in the field.

(A) Release site criteria-One week prior to the releases, sites were selected based on the following criteria: (a) evidence of swift fox activity (old den sites); (b) escape terrain (numerous burrowing animals' holes); (c) proximity to water; and (d) a varied prey base. Predator activity was also noted. These criteria were developed from a survey of swift fox habitat in South Dakota (Smeeton, 1994).

(B) PPS-No more than 2 days prior to the actual release, a PPS was placed at each site. PPS design was based on the existing fox shelters at the CEI. The PPS A-frame is designed so it can be assembled in situ and the three-chambered fox box can be folded up and transported on a packboard. PPS are left at the release sites for a minimum of 4 days after the release.

(C) Release method-Swift foxes at the captivebreeding colony were tattooed and inoculated in their enclosures at least 1 week prior to the date set for release. The tattoos were applied with a Ketchum Tattoo Kit; males were tattooed in the right ear and females in the left ear. Numbering was sequential, beginning with 1 in 1972 and preceded with the letter 'S' (e.g. S122). All animals to be released were inoculated using Duramune DA2LP $+\mathrm{P} v$ (Canine 
Table 1 Summary of the number of swift fox released in the East Block (Wood Mountain) and West Block areas of Grasslands National Park, Saskatchewan, Canada from 1990 to 1997

\begin{tabular}{lll}
\hline & \multicolumn{2}{l}{ Releases } \\
\cline { 2 - 3 } Year & West Block & East Block \\
\hline 1990 & & 51 \\
1991 & & $75(14)$ \\
1992 & 38 & 87 \\
1993 & 24 & 11 \\
1994 & 10 & 9 \\
1995 & 16 & 9 \\
1996 & 7 & 6 \\
1997 & 26 & 51 \\
Total & 121 & 299 \\
\hline
\end{tabular}

Number in parentheses indicates wild-caught, translocated animals

Distemper-Adenovirus Type 2-Parainfluenza-Parvovirus vaccine (modified live virus) Leptospira Bacterin), and Imrab (rabies). The kits born in the captive-breeding colony were inoculated using Duramune at 4 weeks, then at 8 weeks, and immediately prior to release at 5 months. In addition, all kits were inoculated with Imrab immediately prior to release.

On the release date, the animals were trapped in the enclosures, loaded into individual plastic transport kennels and placed in the trucks intended for each release site. The loaded trucks left immediately for the release sites. On arrival at the designated sites, the kennels were set in a semicircle around the already situated PPS. After $20 \mathrm{~min}$, the kennel gates were opened and the swift foxes allowed to come out in their own time. After the animals ceased to show any interest in the kennels, the kennels were removed.

(D) Post-release monitoring-Volunteers monitored the swift foxes at the release sites on a continuous basis for the first $24 \mathrm{~h}$. After the first $24 \mathrm{~h}$, swift foxes were monitored on a daily patrol basis. Activities noted included movement, den preparation and hunting; fresh scat was collected in order to monitor initial hunting activity.

\section{Reintroduction in South Central Saskatchewan}

The reintroduction of swift foxes in South Central Saskatchewan began in 1990. The initial releases in 1990-91 were conducted as part of a government feasibility study (Brechtel et al., 1993). During this period,
126 animals were released in the Wood Mountain area (Fig. 2). Of these, 14 were adult, wild, translocated swift foxes from the USA and 112 were captive-bred animals. All swift foxes were released using the hard release method. The government agencies continued to release swift foxes into the Wood Mountain area until 1997 (Table 1 and Fig. 2).

In 1991, the Canadian Federal Government (Heritage Canada) intensified the acquisition of land in Saskatchewan for the Grasslands National Park. When complete, the park will be the last and largest representation of the short and mixed grass prairie biome in North America. In other words, swift fox habitat will be preserved in perpetuity. At present, the Grasslands National Park is divided into East and West Blocks, bordered by government-owned grazing land and privately-owned ranches. The park shares its southern border with the state of Montana, USA, where most of the adjoining lands are owned by the Bureau of Land Management (BLM) Federal Grazing Land. The East Block encompasses some of the areas where the Wood Mountain releases took place. Until 1991, no releases had taken place in the West Block of the park.

In 1992, in an attempt to advance the reintroduction programme and to both answer some of the questions regarding the suitability of captive-raised animals for reintroduction as well as to explore more effective release techniques, the CEI began a co-operation programme with the Grasslands National Park. The West Block was chosen as a site where captive-bred animals only would be released. From 1992 to 1997, the CEI released captive-bred swift foxes into the West Block area using the PPS method only (Table 1 and Fig. 2).

In addition to the development and use of new release methods, the CEI in partnership with the Government of Saskatchewan began a series of monitoring studies of the southern Saskatchewan populations of swift foxes. These studies were intended to be nonintrusive, causing as little disturbance to the population as possible (CEI, 1994; Harris \& McAdam, 1994; Longmuir, 1994; Michie, 1994a,b,c; Moehrenschlager, 1994; CEI, 1995). The level of effort and type of monitoring used in these studies are presented in Table 2 and the results are summarized in Fig. 3 .

Several problems were associated with the monitoring data, including variations in methods between studies, sampling during different periods of the year, and lack of co-ordination between government and non-governmental organizations (NGOs) in data collection. The data did, however, highlight some differences in animal distribution in the two release areas. Swift fox releases were more scattered in the East than the West Block. In the East Block, up to 1995, 242 swift foxes were released into $1187 \mathrm{sq} \mathrm{km}$, resulting in a 


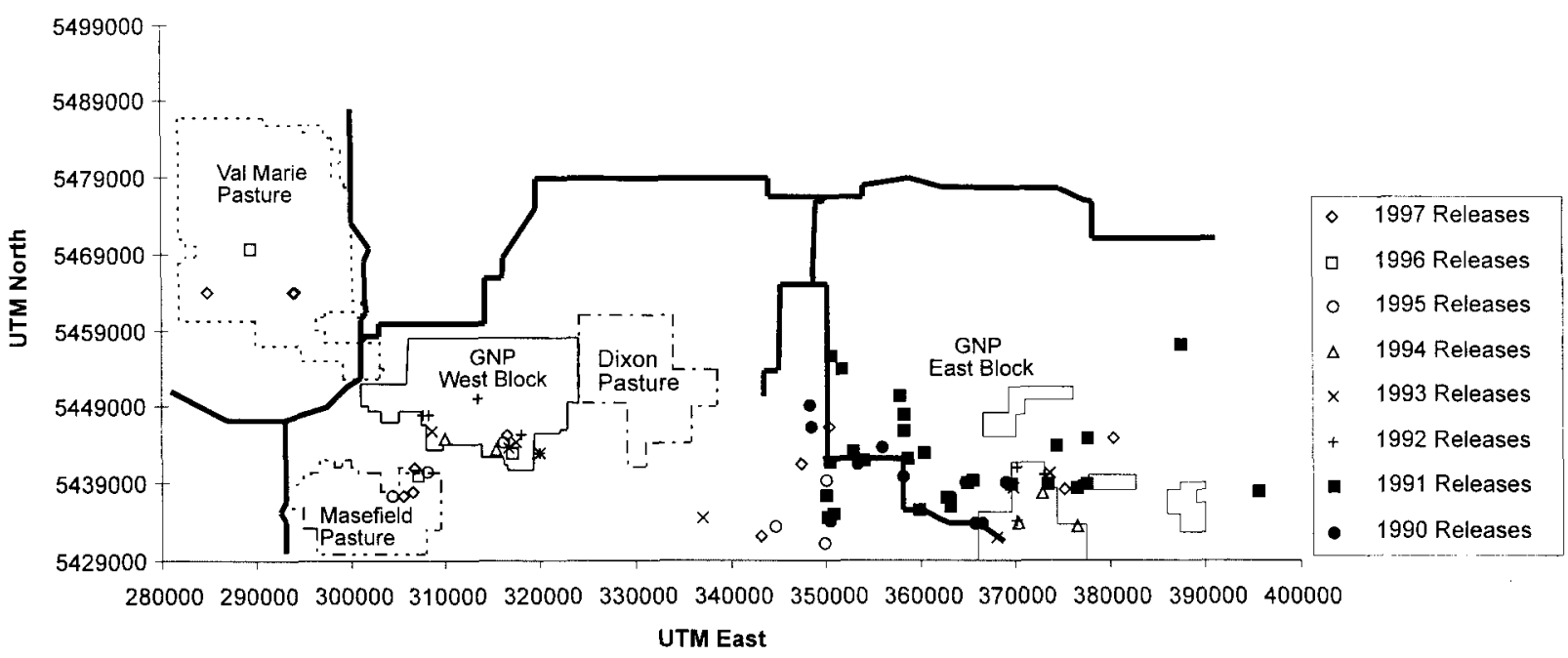

Fig. 2 Release sites locations for swift foxes in South Central Saskatchewan from 1990 to 1997 (locator system shown is the Universal Transverse Mercator Grid, Zone 12, North American Datum 1983).

release density of 0.204 fox per sq $\mathrm{km}$. Meanwhile, over the same period in the West Block, 88 swift foxes were released into an area of $89 \mathrm{sq} \mathrm{km}$, resulting in a release density of 0.989 fox per sq $\mathrm{km}$. The monitoring data showed that by 1995 the population in the East Block occupied an area much smaller than the original release area. In contrast, the swift fox population in the West Block area expanded into new areas and maintained a population in the original release area as well. It was assumed that the swift foxes in the West Block were moving into areas of suitable habitat. The releases in the West Block from 1995 to 1997 showed similar movements as new releases were made into habitat that had been chosen by previously released swift foxes. Unfortunately, only one follow-up study to monitor populations has been conducted since 1995 (Cotterill, 1997).

The effectiveness of the PPS release method was still under review at the time of writing. Initial results are summarized in Table 3. Further evaluation of the methodology is necessary and is being carried out in conjunction with a new reintroduction project at the Blackfeet Reservation, Montana, USA. This study has the advantage of radio-collared swift foxes being released using the PPS method, with extensive postrelease monitoring by graduate students.

In 1997, the governments of Canada, Saskatchewan and Alberta jointly planned and funded a winter trapping survey over what was perceived to be potential swift fox habitat in southern Saskatchewan and Alberta (Cotterill, 1997). In his analysis of the data, Cotterill combined the East and West Blocks of Grasslands National Park into one unit (Wood Mountain). The swift fox density for this area was calculated to be 2.2 foxes per sq $\mathrm{km}$, with a population of 87 individuals. These estimates were not particularly robust because of the methodologies and the number of captures. The main problem resulted from the assumption that the number of animals trapped from random sites could be extrapolated over a much wider area of unknown swift fox habitat potential. The assumption, that utilization of all habitat in the study is the same, could significantly over-estimate the population. It is interesting to note that two of the eight swift foxes trapped in the Wood Mountain area were captive-born, reintroduced animals and six were born in the wild. Population estimates for all the Canadian release areas were 289 individuals with a 95 percent confidence limit of 179-412 individuals.

It has been demonstrated that the swift fox population in South Central Saskatchewan has been reestablished, but the numbers in the wild are low making the survival of this newly established population uncertain. The reintroduction of swift foxes to the Canadian Prairie ended in 1997 because of a lack of financial support from the government. The target number of 420 individuals in the wild, as designated in the National Recovery Plan for the Swift Fox, has not been reached. The future of this unique project is, therefore, doubtful.

\section{Conclusion}

A century of habitat fragmentation and transformation has changed the status of the North American swift fox population from common, widespread and abundant, 
to rare in the USA and extirpated from its range in Canada. The Canadian Swift Fox Reintroduction Programme attempted to re-establish the species in fewer than 14 years (1983-97). Over this period, the release of 841 captive-raised and 91 translocated swift foxes resulted in a change in classification by the COSEWIC (1998) from extirpated to endangered in Canada. Although the reintroduced swift foxes have shown-by surviving, breeding and successfully raising their young in the wild-that their ecological niche still exists, it has not been established conclusively that the present swift fox population in Canada is now at a sustainable level.

The reintroduction of the swift fox into South Central Saskatchewan was accomplished over an 8-year period (1990-97). In this region, the release of 406 captive-

Table 2 Summary of the monitoring effort and methods in South Central Saskatchewan in 1994 and 1995

\begin{tabular}{|c|c|c|c|c|c|c|}
\hline \multirow[b]{2}{*}{ Source } & \multicolumn{2}{|c|}{ Location } & \multirow{2}{*}{$\begin{array}{l}\text { Night lighting } \\
(\mathrm{h})^{*}\end{array}$} & \multirow[b]{2}{*}{ Scent post nightst } & \multirow[b]{2}{*}{ Days in field $\neq$} & \multirow[b]{2}{*}{ Trap nights§ } \\
\hline & West & East & & & & \\
\hline CEI (1994) & $x$ & & & & 23 & \\
\hline Harris \& McAdam (1994) & & $x$ & & 18 & 12 & \\
\hline Longmuir (1994) & & $x$ & & & 7 & 108 \\
\hline Michie $(1994 \mathrm{a}, \mathrm{c})$ & $x$ & & 26 & 127 & 14 & \\
\hline Michie (1994b) & $x$ & & & & 8 & \\
\hline Moehrenschlager (1994) & & $\mathrm{x}$ & 23.5 & 180 & 14 & \\
\hline CEI (1995) & $x$ & & 31.75 & 390 & 64 & \\
\hline McAdam (1995) & & $x$ & 52 & 242 & 37 & \\
\hline Stephens (1995) & $x$ & $x$ & 18 & & 13 & \\
\hline Effort & East $\mathrm{B}$ & & 97.5 & 322 & 76 & 108 \\
\hline Summary & West & & 71.75 & 517 & 116 & \\
\hline
\end{tabular}

${ }^{*}$ Represents the hours spent in the field, during this survey, examining systematically the roadsides for swift foxes with a 500,000 candle power spotlight.

† Total number of scent posts that were placed in the field, for a maximum of 3 nights at the same location, during this survey. Scent posts were baited with sardines and tracks were recorded with either smooth sand or smoked sheet metal.

$\ddagger$ Total number of days spent in the field during the survey, used as an indicator of the level of effort.

$\S$ Total number of nights that live traps were placed in the field during the survey.

East - East Block of Grasslands National Park and Wood Mountain; West - West Block of Grasslands National Park and surrounding area.

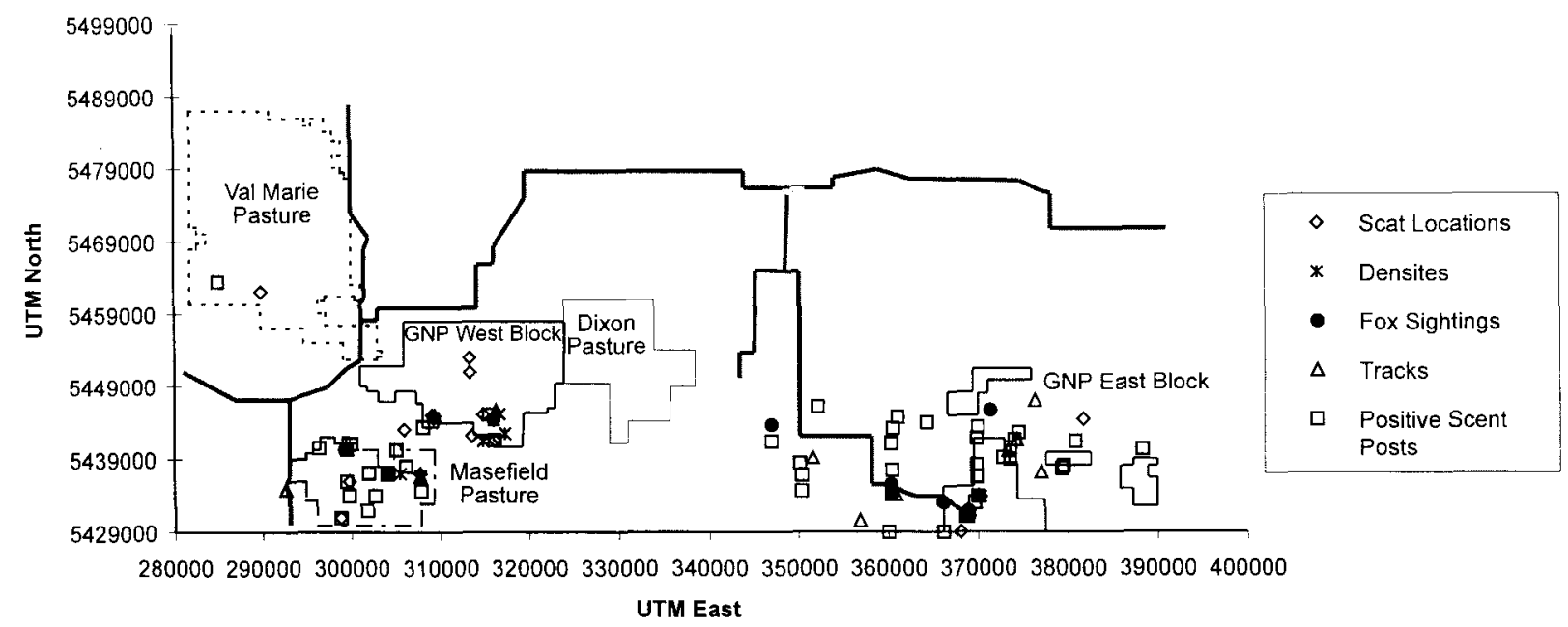

Fig. 3 The location of swift fox signs in South Central Saskatchewan. Data from the monitoring programmes in 1994 and 1995 are outlined in Table 2. The locations represent the distribution of swift fox as a result of the reintroduction programme from 1991 to 1995 (locator system shown is the Universal Transverse Mercator Grid, Zone 12, North American Datum 1983). 
Table 3 Summary of the post-release observations for swift foxes released in the Grasslands National Park using the PPS method from 1993 to 1995

\begin{tabular}{|c|c|c|c|c|c|c|c|c|}
\hline \multirow[b]{2}{*}{ Year } & \multirow{2}{*}{$\begin{array}{l}\text { No. foxes } \\
\text { released }\end{array}$} & \multicolumn{3}{|c|}{ Initial reaction } & \multicolumn{3}{|c|}{ Use of A-frame } & \multirow[b]{2}{*}{ Swift foxes observed at 7 days } \\
\hline & & Bolted & Entered PPS & Investigated area & $24 \mathrm{~h}$ & $48 \mathrm{~h}$ & $72 \mathrm{~h}$ & \\
\hline 1993 & 16 & 12 & 4 & 0 & $11(69)$ & $4(25)$ & No data & No data \\
\hline 1994 & 19 & 8 & 0 & 11 & $4(21)$ & $3(16)$ & $3(16)$ & $6(31)$ \\
\hline 1995 & 23 & 2 & 17 & 0 & $21(91)$ & $13(56)$ & $8(35)$ & $9(32)$ \\
\hline
\end{tabular}

Percentage values are given in parentheses.

raised and 14 translocated swift foxes resulted in an estimated population of 87 individuals by 1997. Associated with these releases were the development of new release methods (notably PPS) and the inclusion of releases in the newly created Grasslands National Park. Although results indicate that the swift fox population has established in this area, more monitoring is necessary to determine whether it is at sustainable levels.

\section{References}

Brechtel, S.H., Carbyn, L.N., Hjertaas, D. \& Mamo, C. (1993) Canadian swift fox reintroduction feasibility study: 1989 to 1992-report and recommendations of the National Recovery Team. Unpublished Report. Alberta Environmental Protection, Edmonton.

Brechtel, S.H., Carbyn, L.N., Erickson, G., Hjertaas, D., Mamo, C. \& McDougall, P. (1994) National Recovery Plan for the swift fox. Report No. 15, March 17, 1994. Recovery of Nationally Endangered Wildlife Committee, Ottawa.

Bremner, S. (1997) Diet and hunting behaviour of captive-bred swift fox (Vulpes velox/Vulpes velox hebes) intended for release. MSc thesis, University of Edinburgh.

Carbyn, L. (1995) Swift foxes on the North American Plains. Canid Action News, 3, 41-45.

Carlington, B.G. (1980) Reintroduction of the swift fox (Vulpes velox) to the Canadian Prairie. Master's degree project, University of Calgary.

CEI (1994) Survey of swift fox activity and possible release sites in Grasslands National Park (15 August to 6 September 1994). Unpublished report.

CEI (1995) Data summary and scent post survey for swift fox in the West Block, Grasslands National Park 1995. Unpublished report. Prepared for Grasslands National Park by Cochrane Ecological Institute, November 1995.

COSEWIC (1978) COSEWIC status reports and evaluations. Volume 1. Official Classification of the Swift Fox as Extirpated in Canada. Committee on the Status of Endangered Wildlife in Canada, Ottawa.

COSEWIC (1998) Canadian species at risk, April, 1998. Committee on the Status of Endangered Wildlife in Canada, Canadian Wildlife Service, Ottawa.

Cotterill, S.E. (1997) Population census of swift fox (Vulpes velox) in Canada: Winter 1996-1997. Unpublished report. For the Swift Fox Recovery Team, Status and Surveys Branch, Alberta Environment Protection, Edmonton.
Flaherty, M. \& Plaake, R. (1986) Response of swift fox (Vulpes velox) to water stress. The Journal of ColorudoWyoming Academy of Science, 18, 51.

Hall, E.R. (1981) The Mammals of North America, vol. 2. John Wiley and Sons, New York.

Harris, W.C. \& McAdam, S. (1994) Assessment of swift fox populations in Saskatchewan-Winter/Spring 1994. Unpublished report. Prepared for Swift Fox Conservation Society, Calgary, and Saskatchewan Environment and Resource Management, Regina, April 1994.

Hjertaas, D. (1994) Reintroduction of the swift fox on the Wood Mountain Plateau. Unpublished report. Saskatchewan Environment and Resource Management, Regina.

ISIS (1989) User Manual for Sparks the Single Population Analysis and Record Keeping System. International Species Information System, Apple Valley, Minnesota.

Longmuir, R. (1994) Live trapping swift fox (Vulpes velox) in the Wood Mountain Area March 1-7, 1994. Unpublished report. Wildlife Population Management Information Base 94-WP-. Saskatchewan Environment and Resource Management, Regina.

McAdam, S. (1995) The Wood Mountain, Saskatchewan swift fox (Vulpes velox) population monitoring project, Summer 1995. Unpublished report. Saskatchewan Environment and Public Safety, Saskatchewan.

Merriam, C.H. (1902) Three new foxes of the kit and desert fox group. Proceeding of the Biological Society of Washington, 15, 73-74.

Michie, J. (1994a) Monitoring of swift fox in Grasslands National Park, November 1994. Unpublished report. Prepared for Cochrane Ecological Institute.

Michie, J. (1994b) Swift fox update in Grasslands National Park, West Block. July 18-26, 1994. Unpublished report. Prepared for Cochrane Ecological Institute.

Michie, J. (1994c) Swift fox monitoring in Masefield and Val Marie PFRA Community Pastures and their suitability as future release sites. Unpublished report. Prepared for Saskatchewan Environment and Resource Management.

Moehrenschlager, A. (1994) Population monitoring of swift foxes (Vulpes velox) by means of scent posting and spotlighting in Wood Mountain Saskatchewan. Unpublished report to Saskatchewan Environment and Resource Management, Regina and the Swift Fox Conservation Society, Calgary.

Pruss, S.D. (1994) An observational natal den study of wild swift fox (Vulpes velox) on the Canadian Prairie. Master's degree project, University of Calgary. 
Reynolds, J. (1983) A plan for the reintroduction of the swift fox to the Canadian Prairies. Master's degree project, University of Calgary.

Schroeder, C. (1987) Swift fox reproductive biology in captivity. Manuscript report, University of Calgary.

Smeeton, C. (1994) Reintroducing the swift fox. Canid Action News, 2, 13-16.

Stephens, P. (1995) Monitoring of swift fox by breeding call playback and other techniques in Grasslands National Park Saskatchewan 23.4.95-7.4.95. Unpublished report. Prepared for Cochrane Ecological Institute, May 1995.

Stromberg, M.R. \& Boyce, M.S. (1986) Systematic and conservation of the swift fox, Vulpes velox, in North America. Biological Conservation; 35, 97-110.

Teeling, E.C. (1996) Born to be free: captive breeding as a conservation technique. Dissertation in part fulfilment of the degree of SMC, University of Edinburgh.

Tudge, C. (1991) Last Animals at the Zoo: How Mass Extinctions can be Stopped. Island Press, Washington, DC.

Uresk, D.W. \& Sharps, J.C. (1986) Denning habitat and diet of the swift fox in western South Dakota. The Great Basin Naturalist, 46, 249-253.

Wayne, R. (1998) A look at swift fox/kit fox taxonomy within the canid complex. First North American Swift Fox Symposium, Ecology and Conservation of the Swift Fox in a Changing World, Saskatoon, Saskatchewan, Canada. February 18-19 1998.

Weagle, K. \& Smeeton, C. (1995) Behavioural aspects of the swift fox (Vulpes velox) reintroduction program.

Proceedings of the 2nd International Conference on Environmental Enrichment, Copenhagen, August 1995.

\section{Biographical sketches}

Clio Smeeton has worked with animals and conservation issues since 1964 when she became Curator of the Children's Zoo at Calgary Zoo, Canada. In 1971, she jointly established, with Miles and Beryl Smeeton, the Wildlife Reserve of Western Canada (now the Cochrane Ecological Institute (CEI)). At the CEI, she has been involved in a wide range of activities, including the breeding of endangered species for reintroduction, the rehabilitation and release of orphaned wildlife, and environmental research and education. The CEI has contributed to the protection and reintroduction of North American bison, trumpeter swans and the swift fox. Clio Smeeton is currently working on a swift fox reintroduction project in the Blackfeet Indian Reserve, Montana, USA.

Ken Weagle began his career in environmental science and management as a student in New Brunswick, Canada, where he worked on the impacts of DDT on aquatic organisms and fish. Since then, he has worked extensively in Canada, the USA and internationally on the management of water-related environmental issues. In 1993, Ken Weagle became the Director of Scientific Programs at the Cochrane Ecological Institute. $\mathrm{He}$ is also the Executive Director of the Mackenzie Valley Land and Water Board, which is currently implementing a new system of community-based environmental and resource management in Canada's Northwest Territories. 